\title{
Macro-habitat preferences by the African manatee and crocodiles - ecological and conservation implications
}

\author{
L. Luiselli ${ }^{1}$, G. C. Akani ${ }^{2}$, N. Ebere $^{2}$, F. M. Angelici ${ }^{1}$, G. Amori ${ }^{3}$, and E. Politano ${ }^{1}$ \\ ${ }^{1}$ Environmental Studies Centre Demetra s.r.l. and Eni s.p.a. Environmental Department, corresponding address: \\ via Olona 7, 00198 Roma, Italy \\ ${ }^{2}$ Department of Applied and Environmental Biology, Rivers State University of Science and Technology, \\ P.M.B. 5080, Port Harcourt, Rivers State, Nigeria \\ ${ }^{3}$ National Research Council (CNR), Institute of Ecosystem Studies, viale dell'Università 32, 00185 Roma, Italy
}

Correspondence to: L. Luiselli (lucamlu@ @in.it)

Received: 24 October 2011 - Revised: 19 June 2012 - Accepted: 21 June 2012 - Published: 4 July 2012

\begin{abstract}
African manatees (Trichechus senegalensis) and crocodiles are threatened species in parts of their range. In West Africa, crocodiles may constitute the main predators for manatees apart from humans. Here, we explore the macro-habitat selection of manatees and two species of crocodiles (West African crocodiles Crocodylus suchus and dwarf crocodile Osteolaemus tetraspis) in the Niger Delta (Nigeria), testing the hypotheses that (i) manatees may avoid crocodiles in order to minimize risks of predation, and (ii) the two crocodile species do compete. The study was carried out between 1994 and 2010 with a suite of different field techniques. We observed that the main macro-habitat types were freshwater rivers and coastal lagoons for manatees, mangroves for West African crocodiles, and rivers and creeks for dwarf crocodiles, with (i) the three species differing significantly in terms of their macro-habitat type selection, and (ii) significant seasonal influence on habitat selection of each species. Null models for niche overlap showed a significantly lower overlap in macro-habitat type use between manatee and crocodiles, whereas the two crocodiles were relatively similar. Null model analyses did not indicate any competitive interactions between crocodiles. On the other hand, manatees avoided macro-habitats where crocodiles, and especially West African crocodiles, are abundant.
\end{abstract}

1

Habitat selection is defined as a non-random use of space by animals resulting from voluntary movements, which can range from simple locomotor responses to behaviorally sophisticated decisions concerning the allocation of time to different parts of a familiar home range (Dill, 1987; Krebs and Kacelnik, 1991). Habitat selection depends greatly on scale, and in animals that move between different environments at different stages of their life cycle, it may be a hierarchic process with various habitat types being selected depending on the proximate needs of the organisms involved (Dill, 1987; Godin, 1997). Hence, habitat selection is often used as synonymous of habitat preference, and is a measure of the degree to which one habitat is selected over another (e.g., Johnson, 1980; Wootton, 1992; Godin, 1997; Pringle et al., 2003).
Being the behavioral component of a species' distributions (Godin, 1997), habitat selection may provide a crucial link between behavioral ecology and population ecology (Rockwood, 2007). Indeed, studies of habitat preferences may have deep impact for not only studies in population ecology but also for conservation when threatened species are involved (e.g., Jones, 2001; Morris, 2003). Therefore, habitat selection theory has been applied to solve numerous problems in the conservation and management of wildlife (Morris, 1996, 2003).

Animals commonly choose among habitats that differ both in foraging returns and mortality hazard (Gilliam and Frazer, 1987). Hence, habitat selection is an important element for determining the density of natural populations of prey, given that prey species must adapt their behaviour to avoid predation (Ricklefs, 1976) and often actively select particular 
habitat types to minimize risks of predation (Crowder and Cooper, 1982; Wootton, 1992; Bowyer et al., 1999; Fortin et al., 2005; Fischhoff et al., 2007). In case of threatened species, it may be of great importance to evaluate to what extent prey behaviour and populations are determined by pursuit of resources versus avoidance of predation. Indeed, in theory, high population densities of predators may affect the conservation programmes for threatened prey species (Roby et al., 2003; Roemer et al., 2006).

In this study, we analyzed the patterns of habitat selection of two crocodile species and one sirenid species which inhabit the freshwater ecosystems of the Niger Delta region (southern Nigeria). More in detail, we analyzed the role of habitat selection (i) in the prey-predator relationships between crocodiles and manatees, and (ii) the potential interspecific competition for space of the two sympatric crocodiles. We quantified:

1. The frequency of records of crocodiles and manatees in relation to main macro-habitat types, habitat type availability, and the co-occurrence of species. This is important given that large crocodiles are thought to be the only predators of manatees together with sharks and humans (Emanoil, 1994; Grigione, 1996), and interspecific competition may drive habitat separation between sympatric crocodiles (Magnusson, 1985).

2. The seasonal variations of habitat preferences frequented by both manatees and crocodiles. This is important because strong inter-seasonal habitat use variations should be expected in freshwater vertebrates inhabiting tropical Africa ecosystems (e.g., Dudgeon, 2000; Shine and Brown, 2008).

We also discuss the main results of this project in the light of conservation implications, given that all species studied here are under threats in different ways (IUCN, 2011) and the Niger Delta environment is one of the most fragile of western Africa (e.g., De Montclos, 1984).

\section{Materials and methods}

\subsection{Study species}

The species under study are:

1. The West African crocodile (Crocodylus suchus), recently separated from Crocodylus niloticus on the basis of genetic and molecular evidence (Hekkala et al., 2011), is a large species up to $5 \mathrm{~m}$ long which may feed upon large prey including ungulates, big cats, and even humans (Welby Aust, 2009). Recent surveys indicated that $C$. suchus is declining or went extinct throughout much of its distributional range (Hekkala et al., 2011) despite not yet being recognized as distinct from $C$. niloticus by IUCN (2011) lists.
2. The dwarf crocodile (Osteolaemus tetraspis), the smallest crocodile of the world is linked to rainforest ecosystems (Riley and Huchzermeyer, 1999). It is considered as Vulnerable by IUCN (2011). This species can reach about $2 \mathrm{~m}$ in length, and feeds mainly crustaceans, fish and small vertebrates (Luiselli et al., 1999; Riley and Huchzermeyer, 2000); this species has been recently splitted from Congo basin populations (which have been named Osteolaemus osborni; Eaton et al., 2009).

3. The African manatee (Trichechus senegalensis), Vulnerable in the whole of its range (Nishivaki, 1984; Reeves et al., 1988; Grigione, 1996; IUCN, 2011), is still a largely unknown herbivore (Reeves et al., 1988; Kane, 1999) despite it has a broad distribution across the main estuaries and rivers in West Africa (Silva and Araújo, 2001).

It is known that African manatees do not have natural predators apart from humans, sharks and crocodiles (Emanoil, 1994). Hence, it is likely that manatees are potentially preyed upon by C. suchus in the Niger Delta wetlands, although no field study on the diets of these crocodiles have been conducted locally.

\subsection{Study area}

The study was carried out in the territory of the River Niger Delta, in southern Nigeria (Fig. 1). This is a densely populated region, extending over about $70000 \mathrm{~km}^{2}$ and makes up $7.5 \%$ of Nigeria's land mass, which consists of present day Bayelsa, Delta, and Rivers States, and in the so-called "South South Zone", also Akwa Ibom State, Bayelsa State, Cross River State, Delta State, Edo State, and Rivers State. The delta is an oil-rich region and is currently one of the most developed regions in Africa (De Montclos, 1984). The delta is also a conservation priority area, given that it is part of an important eco-region (Olson et al., 2001) and one of the earth's biodiversity hotspots (Myers et al., 2000). Along its southern side, the Niger Delta swamp forests is separated from the Atlantic Ocean by a band of mangroves, which can reach up to $10 \mathrm{~km}$ inland. In front of the mangrove belt and close to the sea are ephemeral coastal barrier islands. Over time, the decreasing slope gradient of the Niger River bed and associated lower stream velocities has resulted in an increase of tidal activity in the exits of the numerous distributaries of the River Niger, resulting in the formation of these Coastal Barrier Islands (NEDECO, 1961). The climate of the Niger Delta is characterized by a long rainy season from MarchApril through October. Precipitation increases from the north of the delta (with an average of $2500 \mathrm{~mm}$ ) to the coastal area where mean annual rainfall averages around $4000 \mathrm{~mm}$, making it one of the wettest areas in Africa. The wet season peaks in July, and the only dry months are January and February. However, even during this dry period an average monthly mean of $150 \mathrm{~mm}$ rainfall is recorded in the delta. 


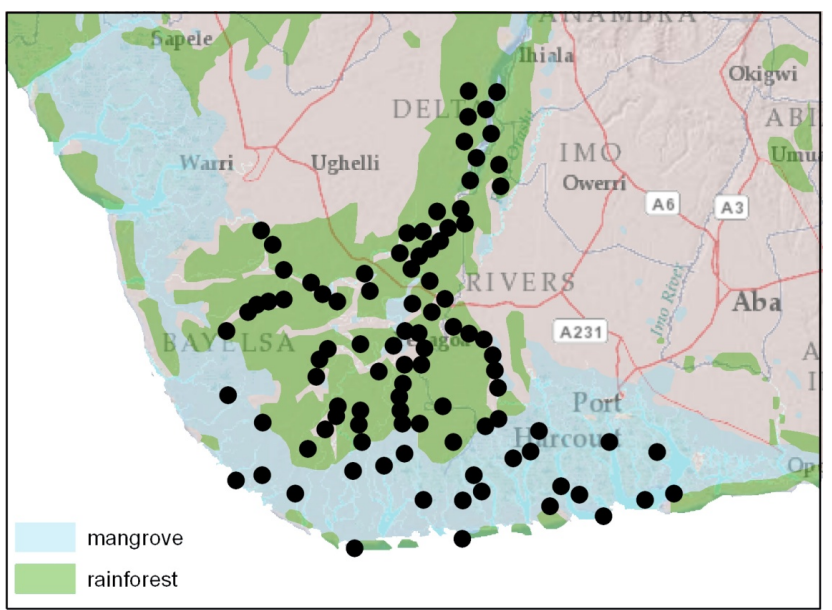

Figure 1. Map of the Niger Delta region, southern Nigeria (West Africa). Dots indicate study sites from where interview and sighting data were obtained.

\subsection{Protocol}

Field research was conducted between September 1994 and September 2010, with an effort of over 100 days per year (in total, over $16000 \mathrm{~h}$ in the field). Data on crocodiles and manatees were collected while the study area was carefully explored for research on freshwater and coastal vertebrates including snakes (e.g., Luiselli, 2006), turtles (e.g., Luiselli et al., 2006), marine turtles (e.g., Akani and Luiselli, 2009) and crocodiles (Akani et al., 1998; Luiselli et al., 1999). Most of the surveys were done as parts of extensive field works logistically organized by international oil companies, mainly T.S.K.J. Nigeria Ltd., ENI, Snamprogetti and Nigerian Agip Oil Company. Over 100 sites located in the vicinities of creeks, rivers, ponds, marshes, lagoons, and along the coasts were surveyed. These sites covered the whole Niger Delta territory and all macro-habitat types (Fig. 1). These sites were classified according to habitat type, with the assumption that sites were located at random in respect to habitat. The presence of crocodiles and/or manatees was ascertained by (i) visual sightings (crocodiles), (ii) examination of specimens or parts of specimens traded in local bush-meat markets or in fetish (ju-ju) markets, (iii) interviews with experienced hunters/fishermen (particularly for manatee; Akani et al., 1998). Visual sightings were done during random surveys (by walking or by canoe) conducted throughout every habitat potentially available to crocodiles and manatees, essentially during daylight hours but also in late evening and at night (Akani et al., 1998). Hundreds of kilometers of rivers and creeks were also covered by means of motor-boats (Akani et al., 1998). We considered only market records for which it was possible to ascertain the exact locality of capture of the traded individuals. Hence, we did not consider about $37 \%$ of the specimens traded (mainly crocodiles). Interviews were accepted only when (i) more than one hunter from a same village reported a given piece of information (for instance, a precise encounter event with a manatee) and (ii) these interviews showed to be consistently reliable by reporting particulars of these events. Based on these criteria, we did not consider about $30 \%$ of the interview data (Akani et al., unpublished data). As for market specimens, for all reliable interview data we recorded also the exact locality of the sightings/capture.

Macro-habitat types were divided into the following categories: (i) coast, i.e., marine sides of the Nigerian coasts; (ii) mangrove, i.e., all river and creek tracts with brackish water and mangroves (Rhizophora and Avicennia spp.) on their banks; (iii) lagoons (including in this category also riverine sites with very wide bed and slowly running current, and lakes); (iv) rivers, i.e., freshwater tracts of main river axis (for instance, Rivers Niger, Nun, Sambreiro, Orashi, New Calabar, etc); (v) creeks, i.e., the network of freshwater creeks connecting the various rivers. Records from freshwater ponds and swamps inside forests patches were assigned to either rivers or creeks depending on their linear distance with the closest creek or river.

\subsection{Statistical analyses}

All variables were tested for normality and homoscedasticity prior applying parametric tests. When non-normal, non parametric tests were used. $\chi^{2}$ tests were applied to explore differences in observed frequencies of crocodiles and manatees among macro-habitat types in relation to expected use if records are randomly assigned to habitats according to their availability. In order to evaluate habitat niche breadth by species, we used Simpson's diversity index (Begon et al., 1996). We used EcoSim software (Acquired Intelligence Corp., Kesey-Bear) to calculate overlap indices and generate Monte Carlo simulations. All other analyses were conducted using SPSS (SPSS 11.0 for Windows) and Statistica (Statistica 6.4 for Windows); all tests were two-tailed with error probability set at 0.05 . To evaluate whether the frequency distribution of the various species was structured randomly, we contrasted the data matrix with random "pseudo-communities" generated by Monte Carlo simulations (Gotelli and Graves, 1996). We calculated Pianka's (1986) overlap formula for crocodiles and manatees and randomized the original species utilization matrices from which Pianka's overlap was calculated by shuffling the original values among resource states. We used two randomization algorithms (RA2 and RA3), as they are particularly robust for niche overlap studies (Gotelli and Graves, 1996). RA2 tests for structure in the generalist-specialist nature of the resource utilization matrix by conserving guild structure, but destroying observed niche breadth (Gotelli and Graves, 1996). RA3 tests for guild structure by conserving niche breadth for each species, but destroying guild structure manifested by the resource utilization matrix's zero structure (Gotelli and Graves, 1996). For each pair of species, 


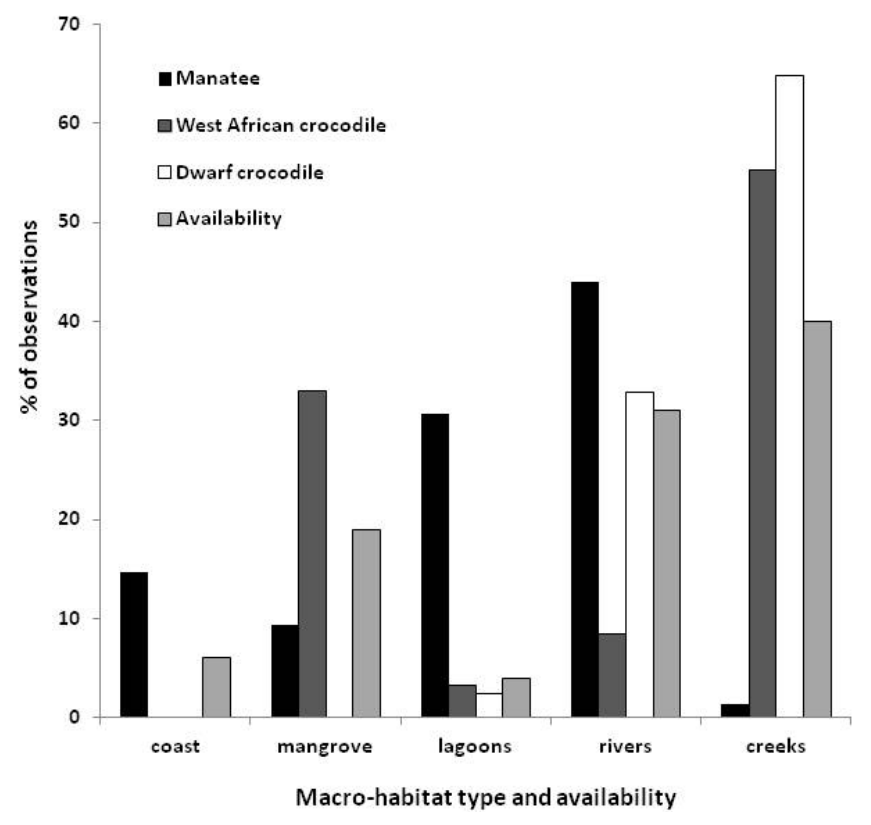

Figure 2. Percent of records of manatee and crocodiles by macrohabitat type in southern Nigeria.

$3 \times 10^{4}$ random Monte Carlo permutations were generated. This amount ensures that algorithm biases are minimized (Lehsten and Harmand, 2006; Luiselli, 2008). Niche overlap values were calculated for each of these randomly generated matrices, and species-pair and community-summary statistics were computed. Actual overlap values were then compared to the distributions of expected values. Structure was assumed when $p_{\text {obs } \leq e x p}=0.05$ (Gotelli and Graves, 1996). In all cases, equiprobable habitat resource use was assumed a priori in the analyses. Based on the $P_{\text {(observed sexpected) }}$ and $P_{\text {(observedzexpected) }}$ values with RA2 and/or RA3, we distinguished three cases: (i) when $P_{\text {(observed } \leq \text { expected) }}<0.05$, then the structure of the assemblage is non-random; (ii) when both $P_{\text {(observed } \leq \text { expected) }}$ and $P_{\text {(observed } \geq \text { expected) }}$ are $>0.05$, then the structure is random; (iii) when $P_{\text {(observed } \geq \text { expected) }}<0.05$, then there is aggregated use of a particular habitat resource (Gotelli and Graves, 1996; Luiselli, 2008). More in detail, a nonrandom assemblage pattern may have several explanations, among which is (i) competition (Gotelli and Graves, 1996), (ii) the fact that species use - based on different evolutionary trajectories - different habitats (Vitt and Pianka, 2005), and (iii) in prey-predator systems (as in our case for the pair manatee and crocodiles) the lower overlap than expected by chance may be due to predator avoidance by the prey.

\section{Results}

\subsection{Record frequency of manatee and crocodiles by macro-habitat type}

Habitat type availability was significantly uneven, with lagoons being the least available habitat and rivers and creeks being the most available habitats $\left(\chi^{2}=49, d f=4, P<0.001\right.$; Fig. 2).

Overall, we collected 75 records of manatees, 94 records of West African crocodiles and 344 records of dwarf crocodiles with macro-habitat type precisely recorded. The three species differed significantly in terms of their macrohabitat type selection ( $\chi^{2}=494, d f=14, P<0.001$; Fig. 2 ). In addition, the frequency of observations in the various habitat types of each species was significantly different from that expected on the basis of the relative habitat type availability (calculated on the absolute values and not on the percentages). More in detail, the manatee was found more frequently than expected in lagoons and rivers and less frequently than expected in creeks $\left(\chi^{2}=140, d f=4, P<0.001\right)$. The West African crocodile was observed more frequently than expected in mangroves and less frequently than expected in rivers $\left(\chi^{2}=34, d f=4, P<0.001\right)$. The dwarf crocodile was recorded significantly more than expected in creeks and significantly less than expected in mangroves $\left(\chi^{2}=141, d f=4\right.$, $P<0.001)$. Pooling rivers and creeks in the category "freshwaters", lagoons and mangroves in the category "brackish waters", and considering marine (coastal) habitats as a third category, it resulted a significant preference of dwarf crocodiles for freshwaters $\left(\chi^{2}=119, d f=2, P<0.001\right)$, of West African crocodiles for brackish waters $\left(\chi^{2}=13, d f=2\right.$, $P<0.001$ ), with the manatee inhabiting freshwaters, brackish waters, as well as marine (coastal) habitats $\left(\chi^{2}=30\right.$, $d f=2, P<0.001)$. There was no significant relationship between availability in the field and use of the various habitat types by crocodiles (Pearson's correlation coefficient after arc-sine transformation of the data - West African crocodile: $r=-0.029, P=0.96$; dwarf crocodile: $r=-0.37, P=0.39$ ) and manatee $(r=-0.26, P=0.57)$.

Simpson's index of habitat niche breadth revealed that dwarf crocodiles were the most specialized of the three taxa studied in terms of macro-habitat type use $\left(S_{\mathrm{i}}=0.45\right)$, with West African crocodiles being intermediate $\left(S_{\mathrm{i}}=0.58\right)$ and the manatee being the least specialized $\left(S_{\mathrm{i}}=0.67\right)$. The differences among species were statistically significant after 5000 Monte Carlo randomizations (observed $F=19.53$, Pseudo- $F=1.46$, variance of the Pseudo- $F$ values $=4.8, P<$ 0.004).

For all three pairs of species we found no significant deviation from the null models (observed index $=0.481 ;$ RA2 algorithm - simulated mean $=0.657$, simulated variance $=0.014, P_{\text {(observed } \leq \text { expected })}=0.086$; RA3 algorithm - simulated mean $=0.487$, simulated variance $=0.022$, $P_{\text {(observed } \leq \text { expected })}=0.560$ ). 

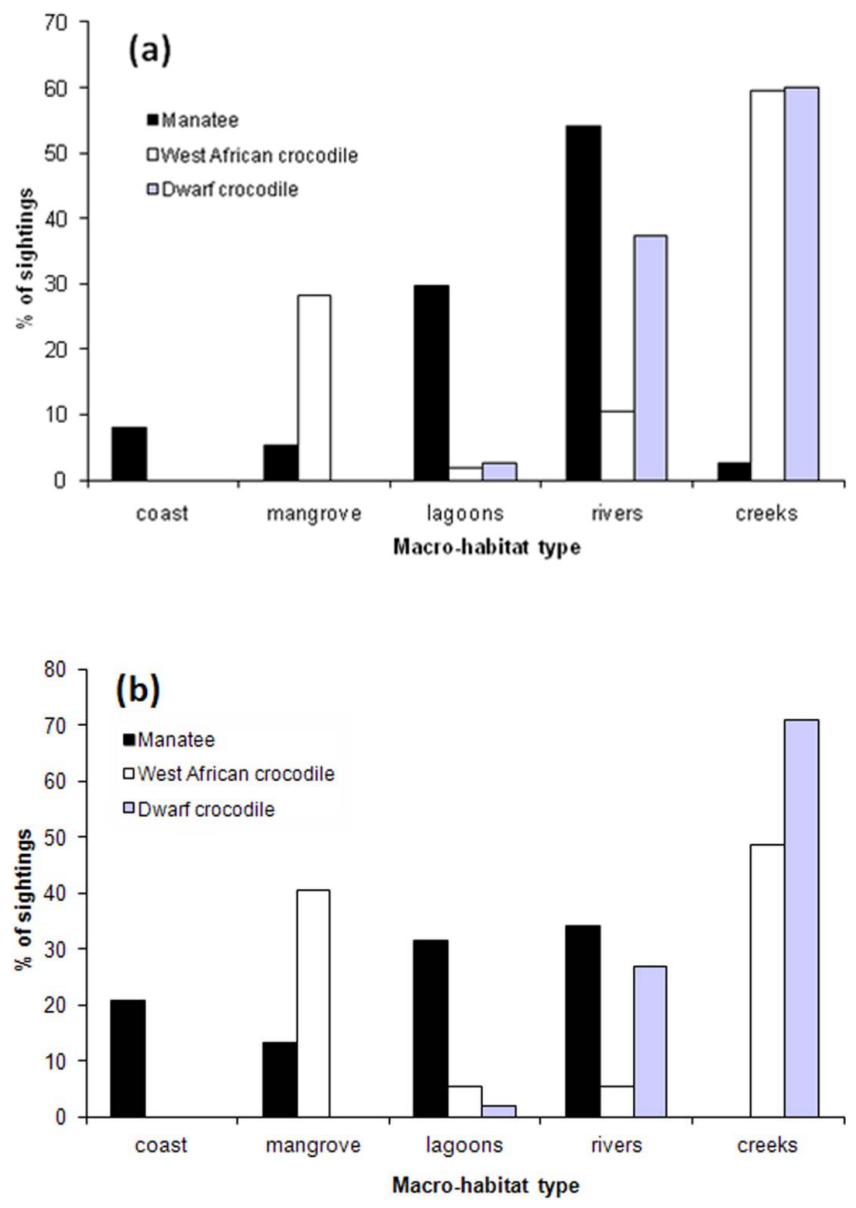

Figure 3. Percent of records of manatees and crocodiles by macrohabitat type in southern Nigeria during the wet season (a) and the dry season (b).

\subsection{Seasonal variations of records of manatee and crocodiles by macro-habitat type}

The distribution of records for both crocodiles and manatee across habitat types and by season is given in Fig. 3. There were marginally significant seasonal differences in macrohabitat preferences by West African crocodiles $\left(\chi^{2}=22\right.$, $d f=3, P=0.051$ ), whereas the inter-seasonal differences in macro-habitat use were highly significant in dwarf crocodiles $\left(\chi^{2}=30, d f=2, P=0.0032\right)$ and manatees $\left(\chi^{2}=8.8, d f=4\right.$, $P=0.026)$. More in detail, the inter-seasonal differences depended on a higher use of (i) creeks by West African crocodiles during the wet season, and (ii) creeks by dwarf crocodiles during the dry season, and (iii) rivers by manatees during the wet season. Manatees also (iv) showed a significantly least use of coasts during the wet season.

Manatees showed low overlap in macro-habitat type use with West African crocodiles in both wet and dry seasons (Fig. 4a for data pooled inter-seasonally and Fig. 4b for data separated by season), whereas their overlap with dwarf crocodiles was also low during the dry season but increased (a)
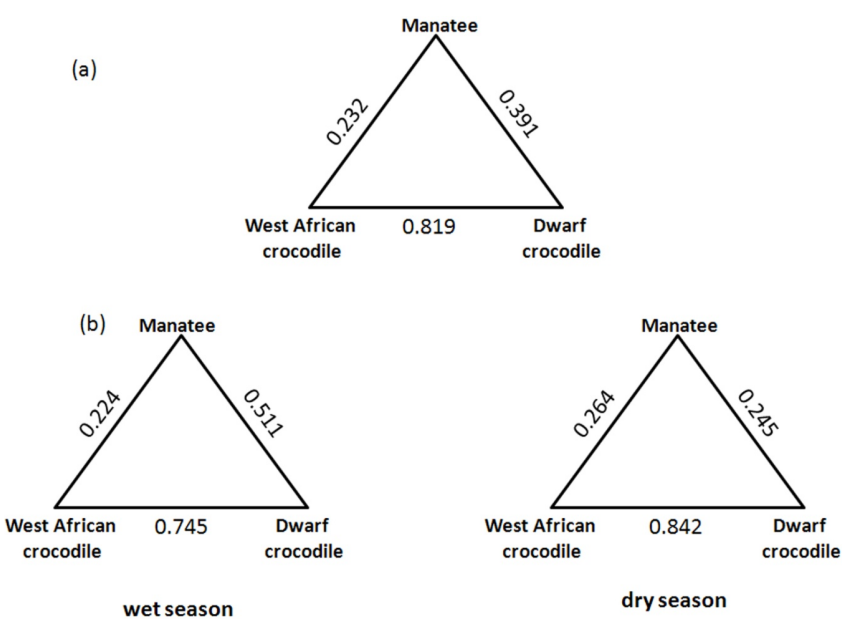

Figure 4. Macro-habitat niche overlap values between crocodiles and manatee at the study area. (a) seasons pooled; (b) seasons separated.

remarkably during the wet season (Fig. 4b). Conversely, West African and dwarf crocodiles showed high overlap values in both seasons (Fig. 4b). For all three pairs of species we found no significant deviation from the null models during both the dry season and the wet season $(P>0.1$ in all cases $)$.

\section{Discussion}

\subsection{Macro-habitat niches}

Our study documented a preference for freshwater bodies by dwarf crocodiles and for brackish waters by West African crocodiles. Manatees were found in all types of waters, with a preference for rivers and for a particular type of brackish waters, lagoons.

The preference of dwarf crocodiles for freshwaters is consistent with earlier literature, reporting that they often inhabit even ponds within the rainforest (e.g., Kofron, 1992; Akani et al., 1998; Riley and Huchzermeyer, 1999). More precisely, the primary habitats used by this species are seasonally flooded swamp-forests in the Niger Delta (this study; Luiselli et al., 1999) and elsewhere (Riley and Huchzermeyer, 1999). Although dwarf crocodiles were not found in mangroves in our study area, they may inhabit this type of habitat in Gabon (Pauwels et al., 2007).

The preference of West African crocodiles for mangroves, and hence brackish water, is probably linked to the local environmental characteristics. Indeed, in the Niger Delta region, freshwaters are typically rainforest rivers, and this large crocodile is well known to avoid water courses with rainforest banks (Dore, 1996; Shirley et al., 2009). It inhabits freshwater courses in the northern Nigeria, where rivers cross through savannah areas (Dore, 1996; Martin, 2008). In East Africa, the Nile crocodile (Crocodylus niloticus), the sister species with $C$. suchus, also inhabits large rivers and creeks 
into the savannah belt, and mangrove creeks as well (Thorbjarnarson et al., 1992). Crocodylus suchus is also known to inhabit a wide range of habitats, from small marshes in the Sahel (Drake et al., 2011) to rainforest localities in the Upper Guinea Forest Basin countries (e.g., Hekkala et al., 2011; this study), and are also known to be abundant in coastal lagoons and in marine environments in the whole of West African region (Shirley et al., 2009; Fergusson, 2010). Thus, our data at the regional level fully confirms anecdotal information available from the whole range of the species.

Manatees exhibited the widest macro-habitat type niche compared to both crocodile species, with dwarf crocodiles exhibiting the narrowest niche width. Indeed, manatees also habitually inhabit both saltwater areas along the coasts (thus contradicting Nishiwaki et al., 1982) and mangrove zones other than freshwater rivers (Emanoil, 1994; Schuhmanhn, 1995; Silva and Araújo, 2001). Similar habitat utilization was also reported for West Indian Trichechus manatus (Powell et al., 1981; Olivera-Gomez and Mellinck, 2005). Thus, our data confirm a general pattern for Trichechus species with a combination of saltwater, brackish water and freshwater systems, represented by rivers, channels and lagoons, being crucial habitats for manatee worldwide (Powell et al., 1981; Olivera-Gomez and Mellinck, 2005). Trichechus manatus presence was also found to be correlated with vegetation cover by aquatic macrophytes (shoal grass and widgeon grass), as these large mammals feed upon these plants (Olivera-Gomez and Mellinck, 2005). The same may well be true for African manatees, which are often sighted close to floating aquatic macrophytes, water lilly (Nymphaea lotus) and water lettuce (Pistia stratiotes) which are dominant in Niger Delta watercourses (Arimoro et al., 2007). African manatees have been also reported to feed on mangrove (Rhizophora sp.) leaves (Husar, 1978; Domning and Hayek, 1986; Reeves et al., 1988), so their sporadic presence within the mangrove belt at our study region can also be due to foraging.

\subsection{Seasonal variations in macro-habitat use}

Our study suggested that season influenced remarkably macro-habitat selection of both manatees and crocodiles. Considering that the knowledge of the ecology of these species is still limited, it is uncertain which reasons are behind the seasonal patterns observed. Nevertheless, we can provide some hypotheses, which all need further investigations. Concerning manatees, their higher use of rivers during the wet season may be due to foraging reasons, given that remarkable increase of floating weed of several plants eaten by manatees (e.g., Nymphaea lotus, Pistia stratiotes, Rhizophora racemosa) occurs at the onset of the wet season in the Nigerian rivers (Hall and Okali, 1974; Fernandes, 1999; Mohammed and Awodoyin, 2008).

With regards to the dwarf crocodile, we suggest that its increased use of creeks during the dry season may depend on their need of escaping from drying off of forest ponds which typically occurs during the dry months. Indeed, forest ponds inundated during the wet months and swamps are the usual habitat of dwarf crocodiles (Thorbjarnarson et al., 1992; Luiselli et al., 1999; Riley and Huchzermeyer, 1999), where they haunt and breed (Kofron and Steiner, 1994). However, when these ponds dry off, the crocodiles should emigrate, and they likely select creeks because of reasons of proximity with their ponds and possibly anti-predatory reasons (see below).

Concerning West African crocodiles, we propose that its higher use of creeks during the wet season may depend on the need of finding open, sunny and sandy areas in which to deposit their eggs, analogously to what happens with the Nile crocodile (see Leslie and Spotila, 2001). Indeed, it is a general trend for crocodiles to show egg hatching during the initial rise in water level at the beginning of the wet seasons (e.g., Thorbjarnarson and Hernández, 1993).

\subsection{Is there any interspecific competition between crocodiles?}

Our null model analyses revealed no indication of competitive interactions between the two crocodile species. We suggest that differences in body size between these species (West African crocodiles being twice as big as a dwarf crocodile on average) may produce differences in diet, thus minimizing competition intensity between these species, as already demonstrated for other reptiles (Pianka, 1973, 1986). Indeed, the two crocodiles also differ in diet composition, with West African crocodiles feeding on small up to large prey (including ungulates and humans; Cott, 1961; Hutton, 1987) and dwarf crocodiles feeding on crabs, fish, arthropods, small vertebrates and even fruits (Luiselli et al., 1999; Pauwels et al., 2007). Moreover, our results clearly show that the two species differ in habitat use, although we could not exclude that habitat type divergence may have been driven by the competition past (Connell, 1980).

\subsection{Does crocodile-avoidance behaviour drive habitat selection of African manatees?}

Despite the manatee showed a significantly wider habitat niche breadth than crocodiles (thus suggesting a higher adaptability to the range of habitat types available in the study region), our correlation analyses suggested that it actively selected habitats which were poorly available in the region, contrary to what both crocodile species did. Hence, we suggest that manatees search specifically poorly available habitat types among the wide variety they are tolerant to, in order to minimize encounters with their potential predators (i.e., crocodiles).

However, in quantitative terms of the factors influencing habitat selection by manatees in West Africa are unkown, although qualitative observations have been done in Guinea 
Bissau (Silva and Araújo, 2001), Sierra Leone (Reeves et al., 1988), Cameroon (Grigione, 1996), and Nigeria (Sodeinde, 1993; Angelici et al., 2001; Blench, 2007). Dwarf crocodiles are certainly too small to constitute a threat for manatees. In contrast, adult West African crocodiles can prey on juvenile manatees, although adult manatees (weighing up to about $500 \mathrm{Kg}$, see Nowak, 1999) are too large for them. If therefore manatees do avoid West African crocodiles, we would expect to find a low overlap between these species in terms of macro-habitat type use. Our data showed that manatees are mainly found in macro-habitat types (coasts, lagoons and rivers) where West African crocodiles are rarely found, and apparently do not frequently occur in macro-habitat types (creeks and mangroves) where the density of West African crocodiles is higher. Although species-specific differences in habitat requirements may be the cause of the observed patterns (see above), this may also be interpreted as active avoidance by manatees of West African crocodiles. Indeed, Nigerian manatees showed a wider macro-habitat type niche than West African crocodiles, and hence they would have been expected to occur frequently also in zones used by their potential predators. For a more convincing test whether manatees really avoid West African crocodiles, we would need comparisons of regions where crocodiles are abundant with regions where they are rare, and analysing how habitat selection by manatees would change. We predict that manatees would appear more habitat generalists and more abundant in mangroves and creeks, in crocodile-depleted areas. Unfortunately, however, no comparative data on the abundances and habitat selection of crocodiles and manatees are available to date (Thorbjarnarson et al., 1992). As a final consideration, it should be mentioned that our manatee records, being based essentially on interviews, may be somewhat biased compared to crocodile records which were almost entirely direct sightings.

\subsection{Conservation considerations}

The data presented here are also potentially of value under the conservation point of view, given that both the dwarf crocodile (Osteolaemus tetraspis) and the manatee (Trichechus senegalensis) are Vulnerable (IUCN, 2011) and that the assessment status of Crocodylus suchus is urgently required. The manatee population in West Africa is reported to have declined, but the species' present range appears to be similar to historic reports (IUCN, 2011). At least for the manatee, it has been demonstrated previously that areas with highest densities lie in close proximity between Cameroon and Nigeria, and that successful manatee conservation will involve working with both Nigerian and Cameroonian communities in order to determine what type of conservation strategy will be most effective (Grigione, 1996).

In terms of population abundance, manatees in Nigeria seem by far rarer than in adjacent Cameroon, where a spotting density of up to five individuals per day was re- ported for wet season samplings in Korup region (Grigione, 1996). Indeed, highest manatee abundance is at the confluence of the Cross and Munaya Rivers where three to five manatees are seen during one sighting several times each year (Grigione, 1996). We also strongly advice scientists to study very carefully manatee habitat selection in relation to crocodiles, because crocodiles may be among the main drivers of local habitat selection of these large aquatic mammals. Indeed, predation rates can be a serious supplementary risk for threatened species (Hecht and Nickerson, 1999), and in some cases it has even been advised that a predator's population removal may be an effective measure for conservation of threatened species (Coté and Suntherland, 1997; Martin et al., 2010).

Concerning crocodiles, our data showed that, at the local scale of Niger delta, dwarf crocodiles are much more abundant than West African crocodiles. This pattern is probably linked to the huge extension of the network of small creeks, swamps, and ponds in flooded and swamp-forests which are found in Niger Delta and which are well known to be the favourite habitat for dwarf crocodiles (Thorbjarnarson et al., 1992; Luiselli et al., 1999; Riley and Huchzermeyer, 1999). Concerning the West African crocodile, it should be noted that this species is particularly vulnerable to extinction because of its rarity and restricted occurrence (Hekkala et al., 2011), especially in countries where illegal harvest of skins, the bushmeat trade, and damage to wetlands are largely unregulated (Shirley et al., 2009). In southern Nigeria, both bush-meat trade and wetland habitat loss and pollution are rampant (Akani et al., 1998; Luiselli et al., 2006), and are certainly affecting crocodile survival. These potential threats should be carefully monitored in the years to come. Exactly the same potential threats are also affecting dwarf crocodile populations. Currently, the populations of dwarf crocodile are still abundant in the Niger Delta region, but specifically focused population studies are needed in order to verify whether their relative abundance is stable or is changing across recent years. No studies of this type are available as yet.

Acknowledgements. The project was funded by Ente Nazionale Idrocarburi (Eni S.p.A.), Nigerian Agip Oil Company, and indirectly by Turtle Conservation Fund (all funds to L. Luiselli). Giuliano Milana, Roland Brandl and anonymous referees are thanked for help and critical suggestions on several draft versions.

Edited by: J. Stadler

Reviewed by: two anonymous referees 


\section{References}

Akani, G. C. and Luiselli, L.: Diversity and distribution of sea turtles in the Niger Delta, Nigeria, Rev. Ecol. (Terre Vie), 64, 369374, 2009.

Akani, G. C., Luiselli, L., Angelici, F. M., and Politano, E.: Preliminary data on distribution, habitat and status of crocodiles (Crocodylus niloticus, Crocodylus cataphractus and Osteolaemus tetraspis) in the eastern Niger delta (Nigeria), Bull. Soc. Herp. Fr., 87-88, 35-43, 1998.

Angelici, F. M., Egbide, B., and Akani, G. C.: Some new mammal records from the rainforests of south-eastern Nigeria, Hystrix (N.S.), 12, 37-43, 2001.

Arimoro, F. O., Ogbeibu, A. E., and Raifu, F. F.: Phytophilous macroinvertebrates of floating Nymphaea lotus and Pistia stratiotes in River Orogodo, Niger Delta, Nigeria, Tropical Freshwater Biology, 16, 75-87, 2007.

Begon, M., Harper, J. L., and Townsend, C. R.: Ecology. Individuals, Populations and Communities, 3rd Edn., Wiley-Blackwell, New York, 1996.

Blench, R.: Mammals of the Niger Delta, Nigeria, Cambridge, 2007.

Bowyer, R. T., Van Ballenberghe, V., Kie, J. G., and Maier, J. A. K.: Birth-site selection by Alaskan moose: maternal strategies for coping with a risky environment, J. Mammal., 80, 1070-1083, 1999.

Connell, J. H.: Diversity and the coevolution of competitors, or the ghost of competition past, Oikos, 35, 131-138, 1980.

Coté, I. M. and Suntherland, W. J.: The effectiveness of removing predators to protect bird populations, Conserv. Biol., 11, 395405, 1997.

Cott, H. B.: Scientific results of an inquiry into the ecology and economic status of the Nile crocodile (Crocodylus niloticus) in Uganda and northern Rhodesia, Transactions of the Zoological Society of London, 29, 211-358, 1961.

Crowder, L. B. and Cooper, W. E.: Habitat structural complexity and the interaction between bluegills and their prey, Ecology, 63, 1802-1813, 1982.

De Montclos, M. A.: Le Nigéria, Kurthala, Paris, 1984.

Dill, L. M.: Animal decision making and its ecological consequences: the future of aquatic ecology and behaviour, Can. J. Zool., 65, 803-811, 1987.

Domning, D. P. and Hayek, L. A.-C.:. Interspecific and intraspecific morphological variation in manatees (Sirenia: Trichechus), Mar. Mammal Sci., 2, 87-144, 1986.

Dore, M. P. O.: Status of crocodiles in Nigeria. Fauna and Flora Preservation Society, London, 1996.

Drake, N. A., Blench, R. M., Armitage, S. J., Barlow, C. S., and White, K. H.: Ancient watercourses and biogeography of the Sahara explain the peopling of the desert, P. Natl. Acad. Sci. USA, 108, 458-462, 2011.

Dudgeon, D.: The ecology of tropical Asian rivers and streams in relation to biodiversity conservation, Annual Reviews of Ecology and Systematics, 31, 239-263, 2000.

Eaton, M. J., Martin, A., Thorbjarnarson, J., and Amato, G.: Species-level diversification of African dwarf crocodiles (genus Osteolaemus): A geographic and phylogenetic perspective, Mol. Phylogenet. Evol., 50, 496-506, 2009.
Emanoil, M.: Encyclopedia of Endangered Species, IUCN and Gale Research Inc., Washington D.C., 1994.

Fergusson, R. A.: Nile crocodile Crocodylus niloticus, in: Crocodiles. Status Survey and Conservation Action Plan, 3rd Edn., edited by: Manolis, S. C. and Stevenson, C., Crocodile Specialist Group, Darwin, 84-89, 2010,

Fernandes, M. E. B.: Phenological patterns of Rhizophora L., Avicennia L. and Laguncularia Gaertn. f. in Amazonian mangrove swamps, Hydrobiologia, 413, 53-62, 1999.

Fischhoff, I. R., Sundaresana, S. R., Cordingleya, J., and Rubenstein, D. J.: Habitat use and movements of plains zebra (Equus burchelli) in response to predation danger from lions, Behavioural Ecology, 18, 725-729, 2007.

Fortin, D., Beyer, H. L., Boyce, M. S., Smith, D. W., Duchesne, T., and Mao, J. S.: Wolves influence elk movements: behavior shapes a trophic cascade in Yellowstone National Park, Ecology, 86, 1320-1330, 2005.

Gilliam, J. F. and Fraser, D. F.: Habitat selection under predation hazard: Test of a model with foraging minnows, Ecology, 68, 1856-1862, 1987.

Godin, J.-G. J.: Behavioural ecology of teleost fishes, Oxford University Press, Oxford, 1997.

Gotelli, N. J. and Graves, G. R.: Null models in ecology, Smithsonian Institution Press, Washington D.C., 1996.

Grigione, M. M.: Observations on the status and distribution of the West African manatee in Cameroon, Afr. J. Ecol., 34, 189-195, 1996.

Hall, J. B. and Okali, D. U. U.: Phenology and Productivity of Pistia stratiotes L. on the Volta Lake, Ghana, J. Appl. Ecol., 11, 709725, 1974.

Hecht, A. and Nickerson, P. R.: The need for predator management in conservation of some vulnerable species, Endangered Species Update, 16, 114-118, 1999.

Hekkala, E., Shirley, M. H., Amato, G., Austin, J. D., Charter, S., Thorbjarnarson, J., Vliet, K. A., Houck, M. S., Desalle, R., and Blum, M. J.: An ancient icon reveals new mysteries: mummy DNA resurrects a cryptic species within the Nile crocodile, Mol. Ecol., doi:10.1111/j.1365-294X.2011.05245, in press, 2011.

Husar, S. L.: Trichechus senegalensis, Mammalian Species, 89, 1-3, 1978.

Hutton, J. M.: Growth and Feeding Ecology of the Nile Crocodile Crocodylus niloticus at Ngezi, Zimbabwe, J. Anim. Ecol., 56, 25-38, 1987.

IUCN.: IUCN Red List of Threatened Species. IUCN, Gland, Switzerland, http://www.redlist.org, 2011.

Johnson, D. H.: The comparison of usage and availability measurements for evaluating resource preference, Ecology, 61, 65-71, 1980.

Jones, J.: Habitat selection studies in avian ecology: a critical review, Auk, 118, 557-562, 2001.

Kane, E.: Trichechus senegalensis (On line), Animal Diversity Web, http://animaldiversity.ummz.umich.edu/, 1999.

Kofron, C. P.: Status and habitats of the three African crocodiles in Liberia, J. Trop. Ecol., 8, 265-273, 1992.

Kofron, C. P. and Steiner, K. P.: Observations on the African dwarf crocodile, Osteolaemus tetraspis, Copeia, 1994, 533-535, 1994.

Krebs, J. R. and Kacelnik, A.: Decision making, in: Behavioral Ecology, and evolutionary approach, 3rd Edn., edited by: Krebs, J. R. and Davies, N. B., Blackwell Scientific Publications, 
Oxford, 105-136, 1991.

Lehsten, V. and Harmand, P.: Null models for species cooccurrence patterns: assessing bias and minimum iteration number for the sequential swap, Ecography, 29, 786-792, 2006.

Leslie, A. J. and Spotila, J. R.: Alien plant threatens Nile crocodile (Crocodylus niloticus) breeding in Lake St. Lucia, South Africa, Biol. Conserv., 98, 347-355, 2001.

Luiselli, L.: Interspecific relationships between two species of sympatric Afrotropical water snake in relation to a seasonally fluctuating food resource, J. Trop. Ecol., 22, 91-100, 2006.

Luiselli, L.: Do lizard communities partition the trophic niche? A worldwide meta-analysis using null models, Oikos, 117, 321330, 2008.

Luiselli, L., Akani, G. C., and Capizzi, D.: Is there any interspecific competition between dwarf crocodiles (Osteolaemus tetraspis) and Nile monitors (Varanus niloticus ornatus) in the swamps of central Africa? A study from south-eastern Nigeria, J. Zool., 247, 127-131, 1999.

Luiselli, L., Akani, G. C., and Politano, E.: Effects of habitat alteration caused by petrochemical activities and oil spill on the habitat use and interspecific relationships among four species of Afrotropical freshwater turtles, Biodivers. Conserv., 15, 37513767, 2006.

Magnusson, W. E.: Habitat selection, parasites and injuries in Amazonian Crocodilians, Amazoniana, 9, 193-204, 1985.

Martin, J., O’Connell Jr., A. F., Kendall, W. L., Runge, M. C., Simons, T. R., Waldstein, A. R., Schulte, S. A., Converse, S. J., Smith, G. W., Pinion, T., Rikard, M., and Zipkin, E. F.: Optimal control of native predators, Biol. Conserv., 143, 1751-1758, 2010.

Martin, S.: Global diversity of crocodiles (Crocodilia, Reptilia) in freshwater, Hydrobiologia, 595, 587-591, 2008.

Mohammed, H. A. and Awodoyin, R. O.: Growth ecology of an Aquatic macrophyte Nymphaea lotus Linn. From Nigerian inland-water, Journal of Plant Sciences, 3, 99-104, 2008.

Morris, D. W.: Coexistence of specialist and generalist rodents via habitat selection, Ecology, 77, 2352-2364, 1996.

Morris, D. W.: How can we apply theories of habitat selection to wildlife conservation and management?, Wildlife Res., 30, 303319, 2003.

Myers, N., Mittermaier, R. A., Mittermaier, C. G., da Fonseca, G. A. B., and Kent, J.: Biodiversity hotspots for conservation priorities, Nature, 403, 853-858, 2000.

NEDECO: The Niger Delta: report on an investigation, Netherlands Engineering Consultants, The Hague, 1961.

Nishiwaki, M.: Current Status of the African manatee, Acta Zoologica Fennica, 172, 135-136, 1984.

Nishiwaki, M., Yamagushi, C. H. I., Shokita, S., Uchida, S., and Kataoka, T.: Recent survey on the distribution of the African manatee, Scientific Reports Whales Research Institute, 34, 137147, 1982.

Nowak, R. M.: Mammals of the world, 6th Edn., John Hopkins, Baltimore, 1999.

Olivera-Gomez, L. D. and Mellink, E.: Distribution of the Antillean manatee (Trichechus manatus manatus) as a function of habitat characteristics, in Bahia de Chetumal, Mexico, Biol. Conserv., 121, 127-133, 2005.

Olson, D. M., Dinerstein, E., Wikramanayake, E. D., Burgess, N. D., Powell, G. V. N., Underwood, E. C., D'amico, J. A., Itoua, I.,
Strand, H. E., Morrison, J. C., Loucks, C. J., Allnutt, T. F., Ricketts, T. R., Kura, Y., Lamoreux, J. F., Wettengel, W. W., Hedao, P., and Kassem, K. R.: Terrestrial ecoregions of the world: a new map of life on earth, Bioscience, 51, 933-938, 2001.

Pauwels, O. S. G., Barr, B., Sanchez, M. L., and Burger, M.: Diet records for the Dwarf Crocodile, Osteolaemus tetraspis tetraspis in Rabi Oil fields and Loango National Park, southwestern Gabon, Hamadryad, 31, 258-264, 2007.

Pianka, E. R.: The structure of lizard communities, Annu. Rev. Ecol. Syst., 4, 53-74, 1973.

Pianka, E. R.: The ecology and natural history of desert lizards, Princeton University Press, Princeton, 1986.

Powell, J. A. and Kouadio, A.: Trichechus senegalensis, in: IUCN 2011, IUCN Red List of Threatened Species, Version 2011.2, www.iucnredlist.org, 2011.

Powell, J. A., Belitsky, D. W., and Rathbun, G. B.: Status of West Indian manatee (Trichechus manatus) in Puerto Rico, J. Mamm., 62, 642-646, 1981.

Pringle, R. M., Webb, J. K., and Shine, R.: Canopy structure, microclimate, and habitat selection by a nocturnal snake, Hoplocephalus bungaroides, Ecology, 84, 2668-2679, 2003.

Reeves, R. R., Tuboku-Metzger, D., and Kapindi, R. A.: Distribution and Exploitation of Manatees in Sierra Leone, Oryx, 22, 7584, 1988.

Ricklefs, R. E.: Ecology, Chiron Press, New York, 1976.

Riley, J. and Huchzermeyer, F. W.: African dwarf crocodiles in the Likouala swamp forests of the Congo Basin: habitat, density, and nesting, Copeia, 1, 313-320, 1999.

Riley, J. and Huchzermeyer, F. W.: Diet and lung parasites of swamp forest dwarf crocodiles (Osteolaemus tetraspis osborni) in the Northern Congo Republic, Copeia, 2, 582-586, 2000.

Roby, D. D., Lyons, D. E., Craig, D. P., Collis, K., and Visser, G. H.: Quantifying the effect of predators on endangered species using a bioenergetics approach: Caspian terns and juvenile salmonids in the Columbia River estuary, Can. J. Zoolog., 81, 250-265, 2003.

Rockwood, L. R.: Introduction to population ecology, Blackwell Scientific Publications, Oxford, 2007.

Roemer, G. W., Coonan, T. J., Garcelon, D. K., Bascompte, J., and Laughrin, L.: Feral pigs facilitate hyperpredation by golden eagles and indirectly cause the decline of the island fox, Anim. Conserv., 4, 307-318, 2006.

Schuhmanhn, J.: Der Manati, Trichechus senegalensis, im Rio Geba, Guinea-Bissau, Natur und Museum, 125, 402-409, 1995.

Shine, R. and Brown, G. P.: Adapting to the unpredictable: reproductive biology of vertebrates in the Australian wet-dry tropics, Philos. T. R. Soc., 363, 363-373, 2008.

Shirley, M. H., Oduro, W., and Yaokokore-Beibro, H.: Conservation status of crocodiles in Ghana and Cote d'Ivoire, West Africa, Oryx, 43, 136-145, 2009.

Silva, M. A. and Araújo, A.: Distribution and current status of the West African manatee (Trichechus senegalensis) in GuineaBissau, Mar. Mammal Sci., 17, 418-424, 2001.

Sodeinde, O. A.: The manatee in Nigeria: its status, demography and natural history and the role in aquatic systems, Chapter 17, 130-137, in: Proceedings of the National Conference on Conservation of Aquatic Resources, Natural resources Conservation Council, Abuja, 1993.

Thorbjarnarson, J. and Hernández, G.: Reproductive ecology of the Orinoco crocodile (Crocodylus intermedius) in Venezuela. i. 
Nesting ecology and egg and clutch relationships, J. Herpetol., 27, 363-370, 1993.

Thorbjarnarson, J., Messel, H., King, W., and Ross, J. P.: Crocodiles: an action plan for their conservation, IUCN, Gland, 1992.

Vitt, L. J. and Pianka, E. R.: Deep history impacts present-day ecology and biodiversity, P. Natl. Acad. Sci. USA, 102, 7877-7881, 2005.
Welby Aust, P.: The ecology, conservation and management of Nile crocodiles Crocodylus niloticus in a human dominated landscape, unpublished Ph.D. thesis, Imperial College, London, 2009.

Wootton, J. T.: Indirect effects, prey susceptibility, and habitat selection: impacts of birds on limpets and algae, Ecology, 73, 981991, 1992. 